Izvorni znanstveni rad

DOI: $10.17234 /$ Croatica.41.7

UDK: 821.131.1-1.09"15"Di Bona, S.

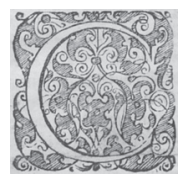

\title{
ALMA CITTÀ DI CUI FATAL IMPERO / SPLENDE HORA E SPLENDERÀ SECOLI E LUSTRI: MITOTVORNA PREDODŽBA O DUBROVNIKU U KANCONIJERU SPERANZE DI BONA
}

\author{
Francesca Maria Gabrielli \\ Filozofski fakultet Sveučilišta u Zagrebu \\ fmgabrie@ffzg.hr
}

U radu se, nakon kontekstualizacijskog uvoda, analizira harmonična slika Grada što je Speranza di Bona (1536-?) - pjesnikinja hrvatskih korijena podrijetlom iz Dubrovačke Republike, koja se rodila i živjela u Manfredoniji - pomno izgrađuje u svojemu kanconijeru na talijanskom jeziku (Difesa de le rime et prose, TPQ 1569). Prilog nastoji osvijetliti kakvu funkciju u okviru značenjske ekonomije razmatranoga djela stječe taj hvalospjevni prikaz koji se usklađuje s interesima dubrovačke vladajuće elite i s mitotvornim predodžbama što ih ona promiče, od primarne ideološke preokupacije epidaurskim podrijetlom Grada do naglaska na izvrsnosti njegova društvenoga i političkog poretka.

Ključne riječi: Speranza di Bona (Nada Bunić), Difesa de le rime et prose, Dubrovnik 


\section{UVOD ILI O OBRANI OBITELJSKE ČASTI}

Polazeći od nezaobilaznoga znanstvenog doprinosa Dunje Fališevac proučavanju ranonovovjekovne dubrovačke književne kulture, a posebice od pomne analize "mehaniz[ama] reciprociteta između kulturne proizvodnje i vladajućih ideologija" koju provodi u knjizi Dubrovnik - otvoreni i zatvoreni grad (2007a: 6), kao i od autoričinih studija koje istražuju stvaralaštvo iz ženskoga pera u starijoj hrvatskoj književnosti (usp. 1995-1996: 123-146; 2001: 33-40; 2003: 118-137; 2007b: 301-325), u radu razmatram, nakon kontekstualizacijskoga uvoda, idealiziran prikaz Grada što ga pjesnikinja Speranza Vittoria di Bona, u struci poznata i kao Nada Bunić, ${ }^{1}$ pomno oblikuje u svojemu kanconijeru na talijanskome jeziku, ${ }^{2}$ a posebice u početnome ciklusu od pet posvetnih soneta u kojima glorificira Dubrovnik i dubrovačku elitu.

Prema pretpostavkama koje sam iznijela na drugome mjestu, Speranza di Bona - autorica hrvatskih korijena, podrijetlom iz Dubrovačke Republike - rodila se 1536. godine u Manfredoniji. ${ }^{3} \mathrm{U}$ apulijskome je gradu, zajedno sa sestrama, majkom i ocem, ${ }^{4}$ živjela barem do 1569 . godine, kada je sročila dugu i polemički intoniranu posvetnu poslanicu kao predgovor svojoj knjizi pod naslovom Difesa de le rime et prose de la signora Speranza, et Vittoria di Bona in difesa di suo honore, et contra quelli, che ricercò farli infamia con sue rime. ${ }^{5}$ Kako doznajemo iz uvodne proze, kojoj je funkcija, kao i svakom paratekstu, da usmjerava čitanje matičnoga teksta (usp. Genette

1 Nenad Vekarić upozorava da se "hrvatsko ime Nada ne može [...] sresti prije kraja 19. stoljeća" te zaključuje da kroatiziranje autoričina imena, kao i imena njezine sestre Giulije, "nema uporišta" (2013: 144, bilješka 23).

2 Posrijedi je enkomijastički i prigodno intonirana "zborna antologija" (choral anthology, o tome vidi barem Hairston 2010: 164; v. i Gabrielli 2015: 94, bilješka 36), tj. autorski kanconijer koji obuhvaća i stihove drugih pjesnika kao sastavni dio matičnoga teksta (dijaloški se povezani tekstovi dopisnih pjesničkih razmjena objavljuju jedni uz druge).

3 Sve kontekstualizacijske napomene u početnom dijelu ovoga rada prenose pretpostavke i zaključke što ih detaljnije iznosim u raspravi posvećenoj kanconijeru Speranze di Bona na koju upućujem (Gabrielli 2015: 83-126). Članak o kojemu je riječ u dodatku donosi transkripciju i prijevod posvetne poslanice (Bona 2015: 127-182).

4 U kanconijeru se pojavljuju imena Speranzinih sestara (djelo sadrži nadgrobnice posvećene Lucreziji i Cassandri te pohvalnice Isabelli, Angeli Mariji i Giuliji), ali ne i imena njezinih roditelja.

5 Budući da na frontispisu nedostaju podaci o nakladniku, mjestu i godini izdanja, nadnevak kojim se zaključuje posvetna poslanica (4. rujna 1569) služi nam kao terminus post quem pri datiranju tiskovine. Naslov knijge u prijevodu glasi: Obrana poezije i proze gospođe Speranze 
1997: 1-2), članovi obitelji Bona su u Manfredoniji bili izloženi dugogodišnjim spletkama kojima su neimenovani "zlotvori" ("scelerati”, f. 2v i passim), sposobni uplesti u svoje podmukle poslove cijelu manfredonijsku zajednicu, za sebe i za ljude s kojima su bili u dosluhu iznuđivali financijsku i drugu korist. Naime, među mnoštvom kriminalnih radnji kojima su manipulativno pribjegavali, narušavajući pritom ugled obitelji, varalice su se drznuli i krivotvoriti razne stihovane i prozne dokumente pod imenom autorice i njezinih ukućana. Zakučasta prijevara, koja je u vrijeme pisanja uvodne proze trajala već petnaest godina, ${ }^{6}$ potakla je Speranzu di Bona da objavi svu svoju dotadašnju književnu produkciju ${ }^{7}$ kako bi se ogradila od zloupotrebe svojega imena te kako bi, razloživši u uvodnoj prozi svoju rekonstrukciju pomno orkestrirane obmane, pokušala stati na kraj varalicama te povratiti čast svojoj obitelji.

Iz posvetne je poslanice razvidno da su za žrtvu svoje beskrupolozne prijevare varalice odabrali laku metu. Posrijedi je naime obitelj koja nije imala rodbinu ni prijatelje u gradu gdje se nastanila - što potkrepljuje pretpostavku da je Speranzin otac bio dubrovački iseljenik - te čiju je društvenu ranjivost otežavala u to doba nepoželjna prisutnost četiriju neudanih kćeri, kao i onemoćalost jedinoga muškog člana, oca, koji je sve ovlasti predao svojoj ženi (usp. Gabrielli 2015: 102). ${ }^{8}$ Slučaj Speranze di Bona omogućuje nam, drugim riječima, da razmotrimo mračnu stranu raširene europske

Vittorije di Bona u obranu njezine časti i protiv onih koji su joj pokušali narušiti ugled svojim stihovima. Na posljednjim, nenumeriranim folijama, od verso-strane 71. do verso-strane 72. folije, pod naslovom koji je samo djelomično čitljiv zbog oštećenja gornjeg ruba folije ("Nota d'alcuni errori [...]"; u prijevodu: "Bilješka o nekim pogreškama [...]"), rukopisno su dopisane korekcije tekstualnoga tkiva tiskovine. Popisu tiskarskih pogrešaka, na verso-strani 71. folije, prethodi uvodna bilješka. Ako nam je vjerovati sadržaju bilješke, riječ je o autografu. Prihvatimo li hipotezu da je tekst nadopisala Speranza di Bona, iz njega ishodi da autorica nije izabrala naslov svoje knjige (usp. Gabrielli 2015: 99-102).

6 Kako ne bi uznemirivale onemoćaloga muškog člana obitelji, majka i kćeri nisu s njim dijelile svoje sumnje u prijevaru koju su počele raskrinkavati 1565 , premda je ona započela $1553, \mathrm{tj}$. od trenutka kada se Speranza di Bona upustila u politički intoniranu pjesničku razmjenu sa sienskom pjesnikinjom Virginijom Salvi (usp. ibid.: 104-105).

7 Usp. sljedeće mjesto u posvetnoj poslanici: "Et i versi miei quali essi sieno per maggior sganno vedranno qui tutti [...]" (f. 18v). U prijevodu: "Da bi se lakše uklonila zabluda, tu će vidjeti sve stihove koji su moji [...]" (Bona 2015: 146, 175).

8 Dubrovnik se u posvetnoj poslanici prikazuje kao grad gdje Speranzin "otac ima svojtu i [...] uživa toliko prijateljstva i iskrenosti" ("dove mio padre ha parenti et tanta amicitia et sincerità", f. 19v), a Manfredonia kao grad gdje je obitelj lišena "prijateljstava i poznanstava" ("dove né amicitia né conoscenza habbiamo", f. 19v). Bona 2015: 148, 177. Na pitanje je li Speranzin 
pojave ranonovovjekovne urbane, a posebice dubrovačko-apulijske migracije. Valja pritom naglasiti da je Speranzin primjer osebujan zato što ona, rođena u Manfredoniji po svemu sudeći od oca Dubrovčanina, u svojoj knjizi ističe, s jedne strane, pripadnost zapadnojadranskoj zajednici, dosljedno koristeći afektivno konotiranu imenicu "domovina" ("patria”, f. 2r i pas$\operatorname{sim})^{9} \mathrm{za}$ apulijski grad u kojemu je došla na svijet, dok se s druge strane ne suspreže označiti istovjetnom imenicom i Dubrovnik, premda samo na jednome mjestu u posvetnoj poslanici, u sklopu sintagme "in quella patria" (“u onoj domovini", f. 19r; usp. ibid.: 89-90). Dvojakom upotrebom imenice "patria" Speranza di Bona izražava dvojnost svoje zavičajne pripadnosti. Međutim, dok autorica apulijski rodni grad, kako u proznome tako i u pjesničkom dijelu knjige, ocrtava u izrazito negativnome svjetlu, njezin prikaz Dubrovnika vazda je panegirički nastrojen.

Tematizacija dihotomije između manfredonijske i dubrovačke sredine čini jedno od glavnih čvorišta knjige hrvatsko-talijanske autorice. Osim proznoga predgovora koji - vehementnim tonom, ali i izrazito hermetično - prikazuje složen splet prijetvornih postupaka na štetu iseljeničke obitelji u kojem sudjeluje cijela manfredonijska zajednica, invektiva protiv apulijskoga grada tematska je okosnica i nekoliko polemičkih pjesničkih sastavaka. ${ }^{10} \mathrm{~S}$ druge strane, Dubrovnik i dubrovačka elita predmet su sustavne hvale, počevši od dedikacijske epistole kojom Speranza di Bona posvećuje svoje djelo dubrovačkom plemiću Mihu Lukareviću (u tekstu: Michele Luccari). Međutim, budući da se konvencionalna enkomijastička funkcija hvale naslovljenika u posvetnoj poslanici izražava tek usputno, jer joj je primarna uloga polemičke i pragmatične naravi, autorica svoj kanconijer započinje, u duhu svojevrsne nadoknade ali i u skladu s konvencijama, ${ }^{11}$ pohvalnim

otac bio dubrovački plemić još uvijek nije moguće odgovoriti. Napominjem da Serafin Cerva sumnja u pripadnost Speranzine sestre Giulije vlasteoskom rodu (usp. Vekarić 2013: 142).

9 Za "emotivno nabijenu" imenicu "patria" usp. Kunčević 2015: 15.

10 Među inima valja spomenuti sonet "prijetvornome A. N." (“Al fraudolento A. N.”, f. 45r), sonete pod naslovom "A Siponto" ("Sipontu", ff. 53v-54r) te ciklus oktava pod istovjetnim naslovom (ff. 52r-53v), u kojemu se, u skladu s pjesničkim postupkom pod nazivom tramutazione, sustavno citira prva oktava šestoga pjevanja Ariostova viteškog spjeva Orlando furioso (usp. Gabrielli 2015: 112 i passim). Imenom Siponto autorica ističe antičko podrijetlo Manfredonije.

11 Onodobne konvencije nalažu da se posveta u proznom obliku može popratiti stihovanim posvetama, koje mogu uključiti hommage naslovljenikovoj obitelji i zajednici (usp. Terzoli 2010: 169-170). Za analizu posvetne poslanice v. Gabrielli 2015: 102-111. 
ciklusom od pet soneta posvećenih naslovljeniku, njegovoj sestri i zavičaju, o kojemu će biti riječi u središnjem dijelu ovoga rada. ${ }^{12}$

Pjesnička zbirka Speranze di Bona započinje dakle u slavu Dubrovnika i dubrovačke elite. Štoviše, ako je točna pretpostavka, koju sam izložila drugom prilikom, o prisutnosti mikrokanconijera autoričine sestre Giulije na posljednjim folijama tiskovine (ff. $65 \mathrm{v}-71 \mathrm{r}$ ), ${ }^{13}$ dio knjige koji zauzima kanconijer Speranze di Bona (ff. 22v-65v) zaključuje se stihovima Nikole Sfondratija (u tekstu: Nicolò Sfondratti), sina dubrovačkoga kancelara, čime prijateljevanje s dubrovačkom elitom pridaje zbirci završni pečat. ${ }^{14}$ Budući da tiskovina sadrži, kako sam već naglasila, Speranzin cjelokupni dotadašnji opus, što vjerojatno vrijedi i za produkciju njezine mlađe sestre Giulije, lirska razmjena s Nikolom Sfondratijem predstavlja najraniji dokaz da se autorica pjesnički dopisivala s dubrovačkim ljudima od pera. U skladu s tim pjesničke doticaje Speranze i posebice Giulije s Mihom Monaldijem i Sabom Bobaljevićem valja datirati u kasnije razdoblje. ${ }^{15}$ Nadalje, nazočnost

12 Kako objašnjava Nenad Vekarić, riječ je o Mihu Nikolinom Luccariju (oko 1536) i njegovoj sestri Madi, supruzi pjesnika Dinka Ranjine (usp. 2013: 143, bilješka 7).

13 Usp. Gabrielli 2015: 91-92, 98-99, 118-121.

14 Usp. ibid.: 96. Riječ je o pjesničkoj razmjeni koju sonetom započinje Nikola Sfondrati, a odgovara mu Speranza di Bona istovrsnim pjesničkim sastavom te slijedeći obrazac istih riječirima. Sekvencu zaključuju dva teksta - sonet i madrigal - iz pera sina dubrovačkog kancelara (usp. ff. 64v-65v). Kako napominje Ćosić, "aristokratski rod Sfondrati uzdigao se u Cremoni već u 12. stoljeću", a Nikola Marinov Sfondrati posljednji je muški predstavnik tog roda u Dubrovniku (Ćosić 2017: 112). Premda zbog zatvorenosti dubrovačkoga patricijata na istočnojadranskoj obali nisu mogli uživati plemićki status, u Dubrovniku su Sfondrati "redom bili najviši državni službenici, koji su tijekom 16. stoljeća razvili pravu tajničku dinastiju" (ibid.: 113). Nikola je svoju "karijeru započeo kao kancelarijski pristav 23. kolovoza 1569." da bi 1572, nakon očeve smrti, "bila prihvaćena njegova molba za položaj kancelara" (Seferović 2007: 67). U posveti svojega političkog traktata Dello stato delle Republiche (1591), Gučetić prikazuje Nikolu kao mladića "velikih vrlina koji i više od toga obećava" (Gučetić 2000: 77). O dubrovačkom patricijatu v. Janeković Römer 1999.

15 Usp. o tome npr. Marković 1970: 49-55; Gabrielli 2015: 97. Miho Monaldi posvećuje sonet objema sestrama te pjesnički prijateljuje s Giulijom, dok u Bobaljevićevu kanconijeru zatječemo pjesmu-repliku Giuliji di Bona. U dubrovačkom pretisku Bobaljevićevih i Monaldijevih stihova pod naslovom Rime del nobil uomo s. Savino de Bobalo Sordo e del signore Michele Monaldi dedicate all'Eccelso Senato della Repubblica di Ragusa (1783) kojim sam se ovom prilikom poslužila možemo pročitati pjesmu-repliku Bobaljevića Giuliji (131), Monaldijev sonet Speranzi i Giuliji (188), Monaldijev sonet Giuliji (216) te razmjenu u oktavama koju započinje Giulia, a pjesnički joj odgovara Monaldi (217). Spomenuti tekstovi dokazuju da je Giulia di Bona nastavila pisati nakon što je objavljena tiskovina Difesa de le rime et prose. To isto međutim ne možemo ustvrditi za Speranzu. Štoviše, Speranza di Bona je u sekvenciji pod naslovom Alle Muse (ff. 61r-62v), za koju smatram da je valja datirati oko 1568, najavila kako odustaje 
Sfondratijevih stihova u autoričinoj zbirci važna je i zato što se iz njih dade zaključiti da je glas o nedaćama kojima je obitelj bila izložena u Manfredoniji dospio do Dubrovnika prije objavljivanja tiskovine. Prvi sonet iz pera dubrovačkoga kancelara naime glasi: ${ }^{16}$

\section{DEL MAGNIFICO NICOLÒ SFONDRATTI FIGLIO DEL CANCELLIERO DELLA ILLUSTRISSIMA SIGNORIA DI RAGUSI}

Deh, perché a me non diede la natura ingegno pellegrino e vago stile sì come a voi, c'ha fatta simile e di questo e di quel con somma cura,

acciò, Speranza, poi nella futura gente l'animo vostro alto e gentile udir facessi et a Battro et a Tile, poi che la patria vostra ciò non cura.

Voi dunque per ben vostro et per l'honore di vostra casa ${ }^{17}$ al focile ponete l'esca ch'agguagli un sì vivace ardore, né per procella adversa unqua stogliete da l'alta impresa il vostro ardito core, né chi vi sturbi fia, se voi vorrete. (f. 64v)

\section{[IZ PERA UZVIŠENOGA NIKOLE SFONDRATIJA, SINA KANCELARA PRESVIJETLE DUBROVAČKE SINJORIJE}

Ah, zašto priroda nije mene obdarila rijetkim talentom i lijepim stilom kao što je vas, pomno vas uskladivši i s jednim i drugim, kako bih, Speranza, vašu visoku i plemenitu dušu mogao obznaniti budućim naraštajima, od Baktra do Tula, kad za to ne mari vaša domovina. Vi dakle za svoje dobro i u ime časti svoje obitelji,

od književnoga stvaralaštva zbog napada koje je doživjela na račun svoje pisane riječi (usp. Gabrielli 2015: 117). O pretpostavci da je pjesnik Dinko Ranjina, suprug Made Lukarević, potaknuo doticaje između sestara i dubrovačkih pjesnika usp. Vekarić 2013: 143, bilješka 7; Gabrielli 2015: 90-91, bilješka 27.

16 Transkripcije i prijevodi soneta koje donosim u ovome radu moji su. Prilikom transkripcije prema suvremenim sam konvencijama uredila interpunkciju, apostrofe i akcente, alternaciju $u$ i $v$ te upotrebu velikih i malih slova. Sve sam kratice razriješila i prenijela znak \& kao et, grafeme $\int$ i $s$ kao $s$, grafem $\beta$ kao $s s$. Ispravila sam tiskarske pogreške i u bilješkama navela izmjene (stanje u predlošku prenijela sam pod navodnicima, a izmjenu nakon dvotočke). Intervenirala sam u predložak prema rukopisnim uputama što ih nalazimo na posljednjim folijama tiskane knjige (u nastavku: err. corr.).

17 "cesa": casa. 
kresivu prinosite paljak ravan vašoj snažnoj strasti. Niti strašne oluje mogu odvratiti vaše hrabro srce od velebnog podviga niti vas itko može omesti ako vi tako budete htjeli.]

U tekstu, koji u hvalospjevnom ključu tematizira strastvene napore što ih naslovljenica ulaže u obranu svoje i obiteljske časti, Manfredonia se prikazuje negativno, kao zajednica koja nije sposobna cijeniti iznimnu Speranzinu plemenitost. S druge strane, laudativni stav muškoga lirskog subjekta, iako u skladu s enkomijastičkim konvencijama, nameće pretpostavku da su Speranza di Bona i njezina obitelj na istočnojadranskoj obali uživali ugled. Autorski kanconijer Speranze di Bona zapečaćuju dakle stihovi koji potvrđuju obiteljsku sponu s Dubrovnikom te se priklanjaju pragmatičnom cilju što ga posvetna poslanica tematizira expressis verbis. Pod uvjetom da je moja hipoteza o opsegu Speranzine zbirke plauzibilna, sklona sam smatrati da zavičajna pripadnost jednoj i drugoj obali glasovitoga dubrovačkog pučanina plemenitih talijanskih korijena predstavlja dodatan razlog što autoričinu zbirku zaključuju upravo njegovi stihovi.

\section{POSVETNI CIKLUS I MIT O DUBROVNIKU}

Kako objašnjava Genette, izricanje veze između naslovitelja i naslovljenika glavna je svrha posvetne poslanice (usp. 1997: 134-136). Stoga birajući kao svojega prvog i najvažnijeg čitatelja pripadnika dubrovačkoga plemstva, Speranza di Bona javno proglašava povezanost svoje obitelji s dubrovačkim patricijatom. Dubrovački vlastelin kojemu Speranza di Bona upućuje svoju posvetu prikazuje se u konvencionalnoj ulozi zaštitnika. Tematika posvetne poslanice daje međutim naslutiti da podrška koju ugrožena obitelj traži od dubrovačke elite prelazi okvir retoričkih normi. Naime, na emfatičnome mjestu zaključka proznoga uvoda kazivačica izražava želju da, zahvaljujući pomoći Miha Lukarevića, zaustavi podmukli manfredonijski napad na sebe i svoju obitelj, poput Herakla koji je, uz Jolajevu pomoć, uspio usmrtiti Hidru (usp. Gabrielli 2015: 107-108). U razmatranome odlomku pojavljuje se igra riječi koja priziva autoričino ime Speranza Vittoria (usp. ibid.). Pojmovi nade ("speme") i pobjede ("vittoria") čvrsto se isprepleću s krepošću plemenitoga naslovljenika:

Et conosciuta, con acerbissima esperienza, che la buggia con la violenza unita, a guisa d'una pestifera Idra, invece d'un capo tronco ne redunda sette, ho preso fe- 
licissimo augurio distruggere di questa fiera il corpo intero sol con quest'arme nel braccio, di quel valore che primieramente nel ciel valse et hora in sì gentilissimo spirito si vede di quei chiarissimi raggi scintillare che mi rendeno certa la speme d'haverne vittoria. (f. 22r; Bona 2015: 151)

[Spoznavši, pregorkim iskustvom, da laži, kad se ujedini sa silom, kao kužnoj Hidri umjesto jedne odsječene glave izraste njih sedam, ponadala sam se da ću uništiti cijelo tijelo te zvijeri rukom oboružanom jedino onom krepošću koja je na nebu vrijedila od iskona i sada u [vašemu] tako plemenitom duhu razvidno bliješti presvijetlim zrakama koje učvršćuju moju nadu da ću je pobijediti. (ibid.:181)]

Istovrstan retorički postupak ponavlja se i na kraju soneta kojim, $\mathrm{u}$ znaku glorifikacije Dubrovnika i dubrovačke elite, započinje kanconijer Speranze di Bona:

\section{AL MOLTO MAGNIFICO ET VIRTUOSO SIGNOR MICHELE LUCCARI NOBILE RAGUSEO, SIGNORA SPERANZA VITTORIA DI BONA}

Poi ch'il nome divin famoso e chiaro

scacciò dal ciel quell'orgogliosa schierra

e rigerolla in pregion scura e nera,

dal riso eterno al pianto eterno amaro,

siami quel gran valor schermo e riparo

contro il fier nido la cui voglia fiera

audace tenta e 'l fin attende e spera

di farsi in crudeltade essempio raro.

Voi che, recasci dal superno regno,

spirto gentil ancor conforme gloria

al nome di virtù più ch'altro ornato,

mostrate come sempre haveste a sdegno,

ogni vita ch'in grembo a voi locato

il desio di mia speme habbia vittoria. (f. 22v)

PREUZVIŠENOME I VRLOMU GOSPODINU MIHU LUKAREVIĆU, DUBROVAČKOM PLEMIĆU, GOSPOĐA SPERANZA VITTORIA DI BONA

[Budući da je ime božansko, slavno i svijetlo s neba izgnalo onu oholu četu i bacilo je u mračnu i crnu tamnicu, iz vječnog smijeha u vječni, gorki plač, neka mi njegova veličanstvena snaga bude štitom i zaklonom protiv nesmiljenoga gnijezda koje bezdušnom i drskom željom, očekujući i nadajući se da će ostvariti svoj cilj, nastoji pružiti rijedak primjer okrutnosti. Vi koji pokazujete da ste pale iz raja nebeskoga oduvijek prezirali, o dušo plemenita čija je slava u skladu s imenom što ga krasi najveća krepost, neka pobijedi svaki život što ga je želja moje nade položila u vaše krilo.] 
Tematska okosnica soneta, u kojemu se manfredonijska zajednica "nesmiljeno gnijezdo" lirske kazivačice ("il fier nido") - uspoređuje s "oholom četom" palih anđela ("quell'orgogliosa schierra"), svojevrstan je hommage naslovljenikovu imenu. Naime, sonet evocira nebeski rat koji u Knjizi Otkrivenja arhanđeo Mihael vodi protiv sila zla:

Uto se zametnu rat u nebu koji je Mihael sa svojim anđelima morao voditi protiv Zmaja. Zmaj i njegovi anđeli prihvatiše borbu, ali je ne mogoše izdržati. I mjesta za njih više nije bilo u nebu. Bijaše zbačen veliki Zmaj, stara Zmija koja se zove đavao - sotona, zavodnik cijeloga svijeta - bijaše zbačen na zemlju i bijahu zbačeni s njime njegovi anđeli (Otk 12, 7-9). ${ }^{18}$

Intertekstualnom evokacijom novozavjetnih redaka bezdušje apulijskoga grada poprima biblijske razmjere, kao i želja ženskoga lirskog subjekta da, zahvaljujući zaštiti dubrovačkoga plemića, nadjača mračne sile Manfredonije. Tekstualno tkivo soneta hiperbolično tematizira binarnu opreku između Dubrovnika i apulijskoga grada, kreposnih sljedbenika Boga i grešnih sljedbenika Sotone, dok zaključni stihovi, aluzijom na značenjsku sferu autoričina imena, kazivačicu još jednom smještaju u moćno i pobožno krilo dubrovačkoga patricijata. Speranzin prikaz Mihe Lukarevića promiče, drugim riječima, političku misao dubrovačke vladajuće elite. Naime, vrlina patricijata - koja se u stihovima glorificira tako što se usklađuje s božanskim planom konačne pobjede dobra nad zlom - temelj je na kojemu počiva politički poredak aristokratske republike. Kako ističe Zdenka Janeković Römer, dubrovačka su vlastela poimala i prikazivala Dubrovnik kao državu "u kojoj vladaju najbolji za opće dobro" (1999: 89). ${ }^{19}$

Premda se u ostalim sonetima enkomijastičkoga ciklusa Manfredonia više ne spominje, sintagma "krasno gnijezdo" ("il bel nido") kojom se u drugome sonetu, također posvećenome Mihu Lukareviću, upućuje na istoč-

18 Biblijske retke navodim prema izdanju Kršćanske sadašnjosti iz 2003.

19 Zdenka Janeković Römer napominje kako je "u političkoj misli humanizma i renesanse vizija države i vlasteoskog staleža bila [...] moralistička". U "državi koja je počivala na ideji o građanskom sporazumu i vrlinama [...]”, "[m]oralna sastavnica morala je biti konstitutivna u političkom djelovanju" (1999: 20). Monopol patricijata povlačio je sa sobom ideju o nasljednosti vrline, koju je filozofski opravdao Nikola Vitov Gučetić, pomirivši, kako ističe Lovro Kunčević, "humanistički topos o vrlini kao rezultatu samodiscipline s aristokratskom idejom o njenoj nasljednosti” (2015: 147). O načinima na koji su dubrovačka vlastela vješto ukomponirala humanističku ideju o plemstvu duha u ideologiju o nasljednoj plemenitosti vidi i Janeković Römer 1999: 283-289. 
nojadranski grad, antinomijski se oslanja na razmatrani prikaz apulijskoga grada kao "nesmiljenoga gnijezda" ("il fier nido"):

Signor, di cui s'honora oggi il bel nido

non men ch'il ciel del sol chiaro e lucente, ch'in ogni effetto il cor vostro ${ }^{20}$ eccellente si mostra di virtude albergo fido,

e non pur questo nostro e l'altrui lido del nome altier di voi sonar ${ }^{21}$ si sente: per farvi noto a la futura gente v'inalza sovra22 il ciel famoso grido.

Et chiaro s'udirà da l'Indo al Mauro girando poi col glorioso nome il pregio ancor de la nova Epidauro.

Farà la fama de sì ricche some del biondo dio corona al carro d'auro per far ch'eterno il gran valor si nome. (ff. $22 \mathrm{v}-23 \mathrm{r}$ )

[Gospodine, čije se danas slavi krasno gnijezdo, ništa manje jasno i blistavo od neba suncem obasjanog, jer se vaše uzvišeno srce vjernim utočištem kreposti kaže u svakom činu, a vaše ponosito ime ne odzvanja samo na našoj obali, već i na tuđoj: povik slave uzdiže vas do neba kako bi vas obznanio idućim naraštajima. Putujući s vašim slavnim imenom, čast će novog Epidaura jasno odjeknuti od Indijskoga oceana do Marokanskog mora. Glas će takva blaga okruniti plavokosog boga u zlatnoj kočiji, kako bi se vrla vrlina zauvijek spominjala.]

Aluzijom na blagdan svetoga Vlaha, koja je upisana u prvi stih, sonet unosi u hvalospjev Mihu Lukareviću podsjetnik na nebesku zaštitu što je Dubrovnik uživa. ${ }^{23}$ Raskošni sjaj prve kvartine - koji kontrastivno priziva tamne demonske slike prethodnoga lirskog teksta te na taj način naglašava dubrovačku pravovjernost - povezuje ljepotu Grada i vrlinu njegova plemića.

\footnotetext{
"nostro": vostro.

"snnar": sonar.

"souza": sovra.

23 O tome kako je dubrovački patricijat koristio blagdanske svečanosti u političke svrhe usp. Janeković Römer 1999: 292-293 i passim. Kako napominje autorica, "ideja posvećenosti države, nebeske zaštite poretka, svoj je vrhunski iskaz dobivala u procesiji sv. Vlaha”: posrijedi je bila "proslava časti grada i vlastele, zalog očuvanja postojećeg društvenog reda, molitva za svečevu zaštitu u budućnosti i prilika za isticanje ugleda i prvenstva vlastele" (ibid.: 300). O blagdanu svetog Vlaha usp. ibid.: 299-303; 374-377.
} 
Glasovitost se adresata oblikuje u drugoj kvartini, opisom hvale koja se široko prostire u vremenu i prostoru. Slava vlastelina i slava Grada, spojene u prvoj tercini, sjedinjuju se sasvim u zaključnim stihovima, postavši krunom plavokosog boga sunca, u blistavom prizoru sjaja i slave koji nas ciklično vraća na incipit soneta.

Identifikacija patricijata i Grada, koja evocira ideju o vlasti prosvijetljene elite, nije jedina poruka soneta kojom se autorica priklanja političkoj ideologiji Dubrovačke Republike. ${ }^{24}$ Naime, sintagmom "la nova Epidauro" (“novi Epidaur”) Speranza di Bona poistovjećuje suvremeni Dubrovnik i drevni Epidaur, usklađujući panegiričko tekstualno tkivo s mitotvornim predodžbama o Gradu što ih promiče dubrovačka vladajuća elita. ${ }^{25}$ Pitanje antičkoga, a poglavito epidaurskoga podrijetla u razmatranome je razdoblju od presudne važnosti jer Dubrovačkoj Republici pridaje prestiž drevnosti te shodno tomu i politički legitimitet, oslanjajući se na renesansnu "epistemološk[u] fascinacij[u] počecima naroda, država i gradova" (Kunčević 2015: 23). ${ }^{26}$ Valja primijetiti da se u srokovnom prostoru tercina značaj imena "Epidauro" suptilno naglašava putem istozvučne, dvosmislene rime "nome": "nome" u desetom i četrnaestom stihu. ${ }^{27}$ Nadalje, riječ "Epidauro", odjekujući u rimama "auro" i "Mauro", blagoglasno reproducira motiv zlatnoga sjaja ("auro") i rasprostranjene slave ("Mauro") Dubrovačke Republike ("Epidauro") i njezina patricijata.

Treći sonet ciklusa Speranza di Bona posvećuje plemkinji Madi Lukarević, Mihovoj sestri:

24 Riječima Zdenke Janeković Römer, u dubrovačkoj političkoj ideologiji “[p]ojam vlastele i pojam Republike bili su značenjski povezani, moglo bi se reći izjednačeni, po mletačkom modelu" (1999: 20).

25 U poglavlju svoje studije na temu mita o Dubrovniku "Diskurs o porijeklu" (2015: 23-80) Kunčević napominje kako teza da su Dubrovnik osnovali Epidaurani postaje u doba renesanse jedan "od najvažnijih mitova starog Dubrovnika" (ibid.: 29). O ideološki uzrokovanim mijenama slike Epidaura u renesansnom razdoblju vidi ibid.: 38-50 i passim. Autor ističe kako se veza između Dubrovnika i Epidaura katkad shvaćala kao "povijesni kontinuitet”, a katkad kao "potpuna identičnost dvaju gradova" (ibid.: 39). O krucijalnoj ulozi mita u ideologiji dubrovačkoga patricijata vidi i Janeković Römer 1999: 13-19.

26 O srednjovjekovnom i renesansnom "uvjerenju da porijeklo otkriva ključne osobine [...] zajednica, a time i tendencije njihova kasnijeg razvitka" (23) v. Kunčević 2015: 23-26.

27 Posrijedi je tzv. "rima equivoca", tj. rimovanje fonetski identičnih riječi različitih značenja. 


\begin{abstract}
ALLA MOLTO MAGNIFICA ET VIRTUOSA SIGNORA MADALENA LUCCARI

Donna gentil, che nostra etade adorni dei più preggiati duon ch'il ciel può dare, e d'un splendor eterno e singolare illustri questi oscuri e foschi ${ }^{28}$ giorni, et se tu Phebo a noi sovente torni unqua sperando a lei ritrovar pare, indarno ti affatichi il ciel girare lasciando di Parnaso i bei soggiorni.

Ma se nei vaghi gioghi d'Helicona farai ch'il suo valor, ch'io adoro e colo, s'oda qual per se stesso alto risona, alhor potrai con più espedito volo, c'havrai degli honor suoi degna corona, aprirne il giorno a l'un e l'altro polo. (f. 23r)
\end{abstract}

\title{
[PREUZVIŠENOJ I VRLOJ GOSPOĐI MADI LUKAREVIĆ
}

Plemenita gospo, ti resiš naše doba najdragocjenijim darovima što ih nebo može dati i osvjetljavaš ove tmurne i mračne dane vječnim i osobitim sjajem. I ako se ti, Febe, često nama vraćaš svagda u nadi da ćeš naći njoj ravnu, uzalud se trudiš obilaziti nebo, napuštajući lijepe odaje Parnasa. No, ako postigneš da na krasnim helikonskim vrhovima visoko odzvanja odjek njezine vrline, kojoj se, štujući je, divim, tad ćeš, jer će te krasiti kruna dostojna njezinih časti, bržim letom njome moći načiniti dan na oba pola.]

Budući da je uzajamna privrženost kazivačice i njezinih sestara, kako sam drugdje napomenula (usp. 2015: 83-85 i passim), jedno od glavnih tematskih uporišta Speranzine zbirke, ne iznenađuje što autorica u panegiričku sekvenciju posvećenu dubrovačkoj eliti uključuje i naslovljenikovu sestru Madu. Patricijska vrlina se i u razmatranome lirskom tekstu artikulira naglaskom na semantičku sferu sjaja, a ponavlja se i prizor Feba koji, u ovom slučaju, nebo obilazi uzalud, u potrazi za osobom koja bi vladiki mogla biti ravna. Premda se na prvi pogled prikaz kreposne plemkinje može doimati sličnim prikazu kreposnog plemića, između dvaju soneta ipak postoje značajne razlike. U pretposljednjem stihu obaju tekstova pojavljuje se imenica

28 "focchi": foschi. 
“corona" ("kruna"). U sonetu posvećenome Mihu Lukareviću, međutim, kruna koja krasi plavokosoga boga simbolizira slavu dubrovačkoga vlastelina i njegova Grada, dok u stihovima koje Speranza upućuje vlastelinki, Apolonova kruna predstavlja tek vrlinu adresatkinje. Povrh toga na Febovu se krunu ovom prilikom aludira samo hipotetski. Naime, kad bi se krepost adresatkinje slavila pisanom riječju, onda bi sjaj sunca bio toliko jak da bi se, protivno zakonima prirode, istovremeno pojavio na oba pola. Razmatrani sonet nameće zaključak da je Speranza di Bona bila upućena u različitost muškoga i ženskog plemićkog statusa u Dubrovačkoj Republici. Kako objašnjava Zdenka Janeković Römer, muški patricijski status određivao se kriterijima čistoće podrijetla i sudjelovanja u vlasti. S druge strane, žensko se plemstvo definiralo jedino podrijetlom, dok je politika čvrsto ostajala izvan dosega dubrovačkih vladika (usp. 1999: 192). ${ }^{29} \mathrm{U}$ skladu s tim u razmatranome se sonetu ne tematiziraju sastavni elementi političke ideologije vladajuće elite kao što su primjerice poistovjećivanje (muškoga) patricijata i Republike te naglasak na epidaursko podrijetlo Grada.

Posvetni se ciklus zaključuje dvama tekstovima u slavu Dubrovnika. Okosnica obaju soneta panegirički je opis dubrovačke slobode. Pojam slobode - koji zauzima ključno mjesto u ideologiji dubrovačke aristokratske republike - označava političku autonomiju u unutarnjim i u vanjskim poslovima. ${ }^{30}$ Dok zaključni sonet enkomijastički tematizira dubrovačku neovisnost u odnosu prema moćnim silama koje ga okružuju, prvi hvali društveno-politički poredak Grada:

29 U Dubrovniku se provodila stroga staleška endogamija pa je u tom pogledu žensko plemstvo bilo izrazito važno. Jedna od značajnih uloga vlastelinki, koje nisu mogle sudjelovati u vlasti, bila je povezivanje roditeljske obitelji s obitelji u koju su ušle nakon vjenčanja (usp. Janeković Römer 1999: 192, 206). O dubrovačkim vladikama u razdoblju humanizma i renesanse usp. ibid.: 192-211. Za položaj plemkinja u 15. stoljeću vidi i Janeković Römer 1993-1996.

30 Kako ističe Zdenka Janeković Römer, u "samoj srži dubrovačke aristokratske ideologije jest pojam slobode u značenju političke autonomije - neovisnosti o vanjskim silama, vlastitog zakonodavstva i upravnog sustava" (1999: 21). O tome vidi i Kunčević 2015: 81-83; 139. Autor razlaže kako je sloboda imala dva međusobno povezana značenja "od ponovnog javljanja republikanske ideologije u srednjovjekovnim gradovima Italije". Prvi je "neovisnost, odnosno situacija u kojoj zajednica sama vodi svoje javne poslove, bez podložnosti volji nekog vanjskog autoriteta", a drugi "republikanski način vladanja, oblik vladavine u kojem krajnji autoritet počiva u kolektivnom tijelu građana, a javne poslove vode izabrani magistrati u skladu sa zakonom" (ibid.: 81-82). 


\section{ALLA ILLUSTRISSIMA CITTÀ DI RAGUSI}

Alma città, che ne preggiate mura seggio ritien de l'antica Epidauro, et in te la sua gloria e '1 suo restauro dispose il ciel; mal grado di natura

l'asprezza ${ }^{31}$ de lo sito, oltra misura vinci ${ }^{32}$ non sol di gemme, argento et auro, d'ordine e leggi che da l'Indo al Mauro pari non ha n'harà ${ }^{33}$ l'età futura,

in te la religione, in te il divino culto con tant'honor s'osserva e tiene che doni altrui di te felici essempi.

Quanto invidia n'havrian Sparta et Athene e la città che già fondò Quirino s'esse nel tuo e tu foste a' suoi tempi. (ff. 23r-23v)

\section{PRESVIJETLOME GRADU DUBROVNIKU}

[Plemeniti grade, koji među svojim dičnim zidinama čuvaš sjedište drevnoga Epidaura, a tebi su njegovu slavu i obnovu povjerila nebesa; unatoč surovoj prirodi mjesta, ti si premoćan ne samo draguljima, srebrom i zlatom, nego redom i zakonima kakvih od Indijskoga oceana do Marokanskog mora niti ima niti će ih ikada biti, u tebi se vjera, u tebi se štovanje Boga s tolikom čašću slavi i čuva da drugima pružaš krasan uzor. Kako bi jalne bile Atena i Sparta i grad kojemu je tvorac Kvirin da u tvojem dobu žive, a ti da si u njihovom.]

U skučenom prostoru četrnaest jedanaesteraca sastavak kondenzira topiku prikaza ustroja grada-države što ga promiče kulturna hegemonija dubrovačkoga patricijata, počevši od primarne ideološke zaokupljenosti epidaurskim podrijetlom, koja suvremeni Dubrovnik, kako sam već istaknula, okrunjuje slavom i institucionalnim nasljeđem drevnog prethodnika. ${ }^{34}$ Nazočnost rime "Epidauro": "auro": "Mauro" povezuje sonet Dubrovniku sa sonetom što ga je Speranza di Bona bila uputila dubrovačkom plemiću, blagozvučno potvrđujući nerazmrsivost spone između vlastele i njihova

\footnotetext{
“appressa": l'asprezza (usp. err. corr.).

32 "uina": vinci (usp. err. corr.).

33 "me dara": n'harà (usp. err. corr.).

34 O tome usp. i bilješku 25 u ovome radu. Valja napomenuti da se Epidaur u renesansnom razdoblju počeo prikazivati "kao rimski grad i stoga kao glavni izvor rimskog identiteta (Romanitas) samog Dubrovnika" (Kunčević 2015: 45, usp. i 38-50).
} 
Grada. Rimom povezanim riječima, koje na eufonijskoj razini artikuliraju značaj epidaurske priče o osnutku, pridružuje se u ovom slučaju i imenica "restauro", kojoj je svrha da ističe identitetsku istovjetnost antičkoga i suvremenog grada. U okviru svojih zidina, političkoga simbola "sigurnosti, slobode i trajanja" (Janeković Römer 1999: 378), Dubrovnik obnavlja nasljeđe i slavu Epidaura jer su tako odredila nebesa. Mit o gradu, što ga Speranza di Bona u svojemu posvetnom ciklusu pomno reproducira, upisuje naime Božju providnost i u priču o počecima. ${ }^{35}$ Naglasak na izrazito nepovoljnom geopolitičkom položaju u prvoj kvartini ("l'asprezza de lo sito"), koji se usklađuje s tradicionalnim dubrovačkim diskursom o neplodnosti područja i nevjerničkom okruženju, ${ }^{36}$ kontrastivno uzdiže gospodarsku ("gemme, argento et auro"), društveno-političku ("ordine e leggi") i religioznu izvrsnost Grada ("il divino culto / con tant'honor s'osserva e tiene"). ${ }^{37}$ U pozadini harmonične slike Dubrovnika kao bogate, uređene i pobožne države stoji, dakako, politički monopol vlastele, koji je predstavljao "jamstvo slobode, zakonitosti i dobrobiti grada” (Janeković Römer 1999: 266).$^{38}$ Iznimna pobožnost zajednice koja postaje uzorom izvan svojih granica suptilno evocira diplomatski diskurs o Dubrovniku kao gradu koji, zbog specifičnosti svoje lokacije, "izvršava misiju u interesu čitavog kršćanstva samim svojim postojanjem" (Kunčević 2015: 175). Egzemplarnost se grada-države naposljetku hiperbolično proširuje na antičku prošlost gdje, svojevrsnim logičkim

35 Lovro Kunčević primjerice napominje kako Cerva u poemi De Epidauro iz 1505. tematizira "božansk[u] nakan[u] iza uništenja Epidaura" (2015: 48).

36 Tipični dubrovački samoviktimizacijski diskurs glede geopolitičkoga položaja (usp. Kunčević 2015: 200) razvidan je u senatskoj uputi iz 1535. koju navodim u prijevodu Lovre Kunčevića: “[...] Naš grad smješten je na kamenitom mjestu, neplodnom i suhom, od kojeg ne možemo dobiti hrane ni da dva mjeseca u godini nahranimo naše podanike i stanovnike. Smješten u raljama nevjernika, za očuvanje slobode i kršćanskog imena plaća ogroman godišnji tribut turskom velikom gospodinu (sultanu) [...].” (2015: 119). Talijanski predložak glasi: “[...] La citta nostra e situata in uno luoco saxoso, sterile et arido, dal quale non pottiamo cauare lo uitto per dua mesi dil anno per uso delli subditi nostri et habitanti. Essendo posta nelle fauci de infideli, per conseruatione della liberta et nome christiano, pagha annualmente uno grossissimo tributo al Gran Signor turco [...]." (Radonić 1935: 374).

37 Progovarajući o osnutku Dubrovnika u prvom poglavlju prve knjige djela Discorsi sopra la prima deca di Tito Livio, Machiavelli u nepovoljnosti sterilne i siromašne lokacije nalazi uzrok dubrovačke radišnosti i društvene sloge. Usp. Machiavelli 1971 [1966]: 130. Usp. o tome Grubiša 2010: 166-167, 179.

38 Dubrovačka vlastela su zakon, "temelj njihove vlasti i jamstvo funkcioniranja države", doživljavala kao "izraz njih samih, njihove političke volje i potreba" (Janeković Römer 1999: 131). 
premetom, suvremeni primjer grada-države nadmašuje svoje drevne prethodnike te im postaje uzorom u hipotetskom scenariju kronološkog obrata. Drugim riječima, spomenom Sparte, Atene i Rima, glavnim antičkim predstavnicima republikanske političke tradicije, tekstualno tkivo izgrađuje poruku o izvrsnosti dubrovačkoga republikanskog uređenja. Speranzin je diskurs i u ovom slučaju u skladu s dubrovačkim autoportretom. Lovro Kunčević naime napominje kako su Nikola Vitov Gučetić i kasnije Junije Resti (Rastić) zagovarali tezu o superiornosti političkoga uređenja Venecije i Dubrovnika u odnosu prema drugim povijesnim primjerima uglednih republika, uključujući i republikanski Rim, te su je opravdavali njihovom višestoljetnom političkom stabilnošću (usp. Kunčević 2015: 149-150). ${ }^{39}$ I Speranzin sonet, prikazom političkoga kontinuiteta koji se proteže od epidaurskoga osnutka do zakonom uređene, uzorne budućnosti, izražava ideju o stabilnosti političkoga poretka Grada.

Zaključni sonet ciklusa započinje blistavim prizorom dubrovačke višestoljetne sudbine, utemeljene u Božjoj providnosti:

Alma città, di cui fatal impero splende hora e splenderà secoli e lustri, né il sol da l'un a l'altro suo emispero par scorge d'honorati homini ${ }^{40}$ illustri,

che ' 1 ciel che ti fondaro ancor ti diero che col girar di lor t'esalti e illustri, d'ogni rara eccellenza anco $\mathrm{ti}^{41}$ fero più d'altra ornata che 'l gran tondo lustri,

sì che non sol l'altrui città di intorno son da celesti e rare doti dome, ma quanto il mar circonda a torno a torno.

La fama risonar fa 'l chiaro nome là onde nasce e dove muore il giorno, portando in sin al ciel l'altiere some. (f. 23v)

[Plemeniti grade, čija sudbinska vlast sad blista i blistat će u vijeke vjekova, a sunce, putujući od jedne do druge polutke, ne sreće časnije i znamenitije ljude, nebesa kojih si djelo podarila su ti da se sve više uzdižeš i proslavljaš kako se ona okreću, i svakom su te rijetkom vrlinom obdarila da budeš gizdaviji od svih što

\footnotetext{
39 O Restiju vidi i Janeković Römer 1999: 391.

40 "hoomini": homini.

41 "ci": ti.
} 
kuglu zemaljsku krase. Svojim nebeskim i rijetkim vrlinama ne krotiš samo druge gradove, već i sve što more oplakuje. Glasovitost širi tvoje sjajno ime tamo gdje se dan rađa i umire, uzdižući tvoju veličanstvenost do nebesa.]

U razmatranom tekstu nanovo se javljaju isprepletene semantičke sfere slave i sjaja koje, i u ovom slučaju, izriču usku povezanost između Grada i njegove časne, znamenite elite ("honorati homini illustri"). I na eufonijskoj razini, gdje dvostruka dvosmislena rima ("lustri": "illustri"; "illustri": "lustri") ${ }^{42}$ istovremeno tvori inkluzivnu i derivatnu rimu ("lustri": "illustri"), ${ }^{43}$ sonet naglašava sjaj, slavu i trajnost Republike. Hvalospjev što ga u ovom tekstualnom tkivu Speranza di Bona izgrađuje proteže se onkraj uzmemirujućih granica Grada, te aluzijom na "nebeske i rijetke" vrline Dubrovčana progovara o vještini vladajuće elite da bez upotrebe sile, dakle diplomatskim umijećem, kroti sve gradove oko sebe, kako bi, u skladu s božjom voljom, Dubrovnik trajno blistao, slavan i slobodan.

\section{LIMINALNI POGLED NA ZATVORENI GRAD}

Prepoznatljiva mitotvorna topika u tekstovima Speranze di Bona svjedoči o njezinu konformističkom stajalištu prema diskursu o Gradu dubrovačkoga patricijata ${ }^{44}$ Razmatrani soneti hrvatsko-talijanske pjesnikinje usklađuju se, drugim riječima, s ideologemima vladajuće elite, promičući identitet Dubrovnika kao "zatvorenoga grada", da se poslužim metaforikom Dunje Fališevac. Ipak, svojim se liminalnim pogledom na izvornu domovinu, koji nastaje u procjepu između hetero i autopredodžbe, Speranza di Bona služi kako bi odgovorila na podmukle napade kojima je izložena u rodnome kraju, po mojemu ga mišljenju usuglasivši upravo u tu svrhu s mitologemima vlasti. Drugim riječima, njezin konformizam, kao izraz pragmatičnih potreba iseljeničke obitelji u neprijateljskom okruženju, istovremeno je i hrabar čin

42 Usp bilješku 27.

43 Posrijedi je tzv. rima inclusiva, tj. rimovanje dviju etimološki nepovezanih riječi od kojih jedna uključuje drugu ("lustri”: "illustri”), te tzv. rima derivativa, tj. rimovanje dviju etimološki povezanih riječi od kojih jedna uključuje drugu ("illustri”: "lustri”).

44 Iva Grgić Maroević ističe da su "enkomijastički soneti [...] kojima se otvara poetski dio knjige, također [...] dio konvencionalnog postupka captatio benevolentiae [...]." (2009: 100, bilješka 17). Valja napomenuti da se u posvetnoj poslanici spominje kako je Speranzin otac u jednom trenutku poželio postati dubrovačkim konzulom (usp. Bona 2015: 177). 
kojim se autorica ovlašćuje na ustanak protiv diskriminacijskoga nasilja sredine u kojoj živi.

\section{LITERATURA}

Biblija. Stari i Novi Zavjet. 2003. Ur. Jure Kaštelan i Bonaventura Duda. Zagreb: Kršćanska sadašnjost.

Bobali, Savino de i Michele Monaldi. 1783. Rime del nobil uomo Savino de Bobalo Sordo e del signore Michele Monaldi dedicate all'Eccelso Senato della Repubblica di Ragusa. Dubrovnik: Carlo Antonio Occhi.

Bona, Speranza di. 2015. Al molto magnifico et virtuoso signore, il signor Michele Luccari, nobile raguseo. Transkr. i prev. Francesca Maria Gabrielli. "Građa za povijest književnosti hrvatske" 38: 127-182.

Ćosić, Stjepan. 2017. Dubrovački rod Radulovića i njihov grbovnik. "Anali Dubrovnik" 55/1: 89-129.

Fališevac, Dunja. 1995-1996. Žena u hrvatskoj književnoj kulturi (od 16. do 18. stoljeća). "Gordogan" 16-17: 123-146.

Fališevac, Dunja. 2001. Women in Croatian Literary Culture, 16th to 18th Centuries. Prev. Celia Hawkesworth. U: Celia Hawkesworth (ur.), A History of Central European Women's Writing. New York: Palgrave Macmillan. 33-40.

Fališevac, Dunja. 2003. Žena-autorica i lik žene u hrvatskoj novovjekoj književnoj kulturi: od XVI. do XVIII. stoljeća. U: Stipe Botica (ur.), Zbornik Zagrebačke slavističke škole 2002. Zagreb: Filozofski fakultet, Zagrebačka slavistička škola - Hrvatski seminar za strane slaviste. 118-137.

Fališevac, Dunja. 2007a. Dubrovnik - otvoreni i zatvoreni grad. Studije o dubrovačkoj književnoj kulturi. Zagreb: Naklada Ljevak.

Fališevac, Dunja. 2007b. Hrvatska ranonovovjekovna književnost iz rodne vizure. U: Dunja Fališevac, Stari pisci hrvatski i njihove poetike. Zagreb: Hrvatska sveučilišna naklada. 299-325.

Gabrielli, Francesca Maria. 2015. Sestra sestri: bilješke o kanconijeru Nade Bunić (Speranze di Bona). "Građa za povijest književnosti hrvatske" 38: 83-126.

Genette, Gérard. 1997. Paratexts: Thresholds of Interpretation. Prev. Jane E. Lewin. Cambridge: Cambridge University Press.

Grgić Maroević, Iva. 2009. Glas Dobre Nade u šesnaestostoljetnom Dubrovniku. U: R. Jambrešić Kirin i S. Prlenda (ur.), Glasom do feminističkih promjena. Voicing feminist concerns. Zagreb: Institut za etnologiju i folkloristiku te Centar za ženske studije. 93-104.

Grubiša, Damir. 2009. Oblici vlasti u renesansi: jedinstvenost dubrovačkog modela. "Politička misao" 46/4: 165-182.

Gučetić, Nikola Vitov. 2000. O ustroju država. Ur. i napisao uvodnu studiju Marinko Šišak. Prev. Snježana Husić i Natka Badurina. Zagreb: Golden marketing i Narodne novine. 
Hairston, Julia L. 2010. Di sangue illustre \& pellegrino: The Eclipse of the Body in the Lyric of Tullia d'Aragona. U: Julia L. Hairston i Walter Stephens (ur.), The Body in Early Modern Italy. Baltimore: The Johns Hopkins University Press. 158-175.

Janeković Römer, Zdenka. 1993-1996. Noble Women in Fifteenth-Century Ragusa. "East Central Europe" 20-23/1: 141-170.

Janeković Römer, Zdenka. 1999. Okvir slobode: dubrovačka vlastela između srednjovjekovlja i humanizma. Zagreb - Dubrovnik: Zavod za povijesne znanosti HAZU u Dubrovniku.

Kunčević, Lovro. 2015. Mit o Dubrovniku: diskursi o identitetu renesansnoga grada. Zagreb - Dubrovnik: Zavod za povijesne znanosti HAZU u Dubrovniku.

Machiavelli, Niccolò. 1971 [1966]. Discorsi sopra la prima deca di Tito Livio. U: Ezio Raimondi (ur.): Opere di Niccolò Machiavelli. Milano: Mursia. 123-396.

Radonić, Jovan (ur.). 1935. Dubrovačka akta i povelje, II/1. Beograd: SKA.

Seferović, Relja. 2007. Strani učitelj i domaći povjesničar: Nascimbene Nascimbeni i Serafin Cerva o retorici. "Anali Dubrovnik” 45: 47-116.

Terzoli, Maria Antonietta. 2010. I margini dell'opera nei libri di poesia: Strategie e convenzioni dedicatorie nel Petrarchismo italiano. "Neohelicon" 37: 155-180.

Vekarić, Nenad. 2013. Vlastela grada Dubrovnika, 4. Odabrane biografije $(A-D)$. Zagreb - Dubrovnik: Zavod za povijesne znanosti HAZU u Dubrovniku.

\section{SUMMARY}

ALMA CITTÀ DI CUI FATAL IMPERO / SPLENDE HORA E SPLENDERÀ SECOLI E LUSTRI: THE IDEALIZED REPRESENTATION OF DUBROVNIK IN SPERANZA DI BONA'S CANZONIERE

In the first five sonnets of her canzoniere (Difesa de le rime et prose, TPQ 1569), Speranza di Bona (1536- ?) - a poet of Ragusan origin, born in Manfredonia - offers an idealized portrait of the city-state of Dubrovnik. This paper presents a close reading of the aforementioned poetic texts and explores the function they perform within the collection, analyzing in particular the ways in which the sonnets comply with the mythic depiction of Ragusa promoted by the ruling elite, faithfully echoing, for instance, the patriciate's ideological preoccupation with the city's Epidaurian origin and the emphasis on its political and social excellence.

Keywords: Speranza di Bona (Nada Bunić), Difesa de le rime et prose, Dubrovnik 